Ethos (Jurnal Penelitian dan Pengabdian Masyarakat): 136-141

\title{
Sifat Komposit BaHan Serat AKar Wangi Dan Limbah SERbuk GergaJI Sebagai Bahan Peredam Suara
}

\author{
The NATUre COMposite of Vetiver Fiber AND THE WASTE OF POWDER SAWN \\ AS AN SOUND ABSORPTION MATERIALS \\ Purwanto
}

Program Studi Desain Produk, Fakultas Arsitektur dan Desain, Universitas Kristen Duta Wacana Jl. Dr.
Wahidin Sudirohusodo 5-25 Yogyakarta
Email: pur@staff.ukdw.ac.id

\begin{abstract}
The increasing use of composites in all fields is engineered materials that many people do to obtain the new alternative materials, one of the materials such as natural vetiver fiber (SAW) which is strong and lightweight and powder sawn (SGK), which is waste material. In this research, manufacturing the composite of SAW and SGK then testing acoustic/absorption power by measuring the absorption coefficient of the sound and the observation of microstructure. The method used in the study is an experiment in the laboratory to make composites based on the ratio of the weight fraction between $S A W$ and $S G K$ from 1: 5, 2: 5, 3: 5, 4: 5 and 5: 5 . Having formed the composites, then the specimen has made by an acoustic test that compatible to ASTM E-1050-98 standard with B \& K 4206 Small Tube Set test instrument. Furthermore, to determine the composition of fibers in the composites, there do the micro observation. From the results of the show the composites produced the sound absorption ability for the low frequency $(1000 \mathrm{~Hz})$ with an absorption coefficient $(\alpha)$ of 0.25 occurred in comparative fraction of 2: 5 (SAW20, SGK50). While at high frequency $(5000 \mathrm{~Hz})$ has a value of coefficient $(\alpha)$ of 0.41 occurred in the ratio of 1: 5 (SAW10, SGK50). The number of composition number fiber influence the composite tensile strength and micro observations occurred in the composition ratio of 5: 5 its highest strength.
\end{abstract}

Keyword: composites, natural fibers, wood sawdust

\begin{abstract}
Abstrak. Meningkatnya penggunaan komposit di segala bidang merupakan rekayasa bahan yang banyak dilakukan orang untuk mendapatkan bahan alternatif yang baru, salah satu bahan tersebut adalah serat alam akar wangi (SAW) yang mempunyai sifat dasar kuat dan ringan dan serbuk gegajian kau (SGK) yang merupakan bahan limbah. Dalam penelitian ini dilakukan pembuatan komposit SAW dan SGK kemudian dilakukan pengujian akustik/daya redam dengan mengukur koefisien peredaman terhadap suara dan pengamatan struktur mikronya. Metode yang digunakan dalam penelitian adalah eksperimen di Laboratorium dengan membuat komposit berdasarkan perbandingan fraksi berat antara SAW dan SGK mulai 1:5, 2:5, 3:5, 4:5 dan 5:5. Setelah terbentuk komposit dibuat specimen uji akustik sesuai standart ASTM E-1050-98 dengan instrument uji B \&K 4206 Small Tube Set. Selanjutnya untuk mengetahui komposisi serat pada komposit dilakukan pengamatan strukturnya secara mikro. Dari hasil penelitian menujukan bahwa komposit yang dihasilkan mempunyai kemampuan redam terhadap suara yang paling baik untuk frekuensi rendah $(1000 \mathrm{~Hz})$ dengan nilai koefisien peredaman ( $\alpha$ ) sebesar 0,25 terjadi pada perbandingan fraksi 2:5 (SAW20,SGK50). Sedangkan pada frekuensi tinggi $(5000 \mathrm{~Hz})$ mempunyai nilai koefisen $(\alpha)$ sebesar 0,41 terjadi pada komposisi perbandingan 1:5 (SAW10,SGK50). Komposisi jumlah serat mepengaruhi kekuatan tarik komposit dan hasil pengamatan secara mikro terjadi pada komposisi perbandingan 5:5 kekuatan tariknya paling tinggi.
\end{abstract}

Keyword : komposit, serat alam, serbuk gergajian kayu 


\section{Pendahuluan}

Komposit merupakan rekayasa bahan yang banyak dilakukan orang untuk mendapatkan suatu bahan baru sebagai bahan dasar alternatif yang mempunyai sifat-sifat sesuai dengan yang diinginkan dan lebih baik dari sifat-sifat bahan sebelumnya. Dalam pembuatan bahan komposit bisa digunakan bahan alami maupun bahn sintetis, namun saat ini komposit dengan material penyusun sintetis mulai beralih pada komposit dengan material penyusun dari bahan alami (Ismail H, 2008). Banyak sekali fakta yang menunjukkan makin meningkatnya prospek pengembangan komposit serat alam diantaranya pembuatan komposit dari bahan serat alam yaitu serat sabut kelapa, serat batang pisang, serat jerami, serat enceng gondok, serat mendong, serat abaca, serat rosella dan serat goni, serat pandan wangi (Pandanus amaryllifolius Roxb), kenaf, dan masih banyak serat alami yang lain yang biasa dimanfaatkan. Beberapa kelebihan serat alam, yaitu mudah diperoleh terutama di daerah tropis, budidayanya serat alam mudah, usia panen relatif pendek, penanamannya dapat dilakukan di lahan marjinal, teknologi untuk pengolahannya sangat sederhana, tingkat sustainabilitasnya sangat tinggi (Shauw A.H 2008).

Salah satu jenis komposit yang bisa digunakan adalah antara bahan alam serat akar wangi dan limbah serbuk gergajian kayu. Kedua bahan ini banyak dijumpai dan merupakan bahan yang mempunyai sifat yang ringan, untuk bahan serat akar wangi mempunyai kekeuatan tarik yang baik sehingga banyak orang memakainya untuk membuat tali maupun dianyam untuk membuat alas duduk pada kursi. Serat alam sekarang banyak digunakan disamping karena jumlahnya banyak dan murah harganya, disamping itu serat alam ini merupakan bahan baku terbarukan serta dapat didaur ulang sehingga sering dimanfaatkan sebagai material penguat.

\section{Limbah Serbuk Gergajian Kayu dan Serat Alam Akar Wangi}

Ketersediaan limbah serbuk gergaji kayu dan penyebarannya hampir merata di seluruh Indonesia, sedangkan tanaman akar wangi yang dalam bahasa latinnya Vetiveria Zizanioides, tumbuh dan berkembang di negara-negara yang beriklim tropis. Untuk itu dalam penelitian yang dilakukan ini merupakan pemanfaatan limbah-limbah alam dengan membuat material komposit dari serat alam akar wangi dan serbuk gergajian kayu sebagai bahan dasar alternatif untuk bahan peredam suara.

Beberapa komposit serat alam mencapai sifat mekanik yang setara dengan komposit fibreglass, dan sudah diterapkan misalnya, dalam industri mobil dan mebel.Karakteristik Kekuatan Bending Kayu Komposit Polyester diperkuat Serat Pandan Wangi dengan Filler Serbuk Gergaji Kayu diperoleh hasil bahwa fraksi volume dan panjang serat pandan wangi mempengaruhi kekuatan bending kayu komposit polyester (Nasmi Herlina Sari dkk, 2013). Chodhury.D (2010) melakukan penelitian tentang komposit serbuk gergajian kayu mendapatkan hasil bahwa sifat mekanik komposit seperti, kekuatan tarik, kuat lentur, komposit sangat dipengaruhi oleh jenis kayu. Sementara itu pada material komposit serat pandan wangi polyester dan komposit serat gelas polyester menunjukkan bahwa semakin panjang serat yang digunakan kekuatan bending dari dua jenis komposit akan semakin meningkat. Begitu juga dengan variasi volume serat, semakin besar volume serat yang digunakan kekuatan bendingnya juga akan semakin meningkat (Emmy Dyah S, 2012). 


\section{Pemanfaatan Limbah Serbuk Gergajian Kayu (SGK) dan Serat Akar Wangi (SAW)}

Konsumsi kayu olahan dalam negeri lebih besar dibandingkan dengan produk kayu yang diekspor, meskipun ekspor produk kayu olahan sangat potensial untuk dikembangkan. Menurut Dubes RI untuk kerajaan Belgia dan Uni Eropa Arif havas Oegroseno (www.antaranews.com, 06 Mei 2014), mengatakan ekspor kayu dan produk kayu Indonesia ke Uni Eropa dalam enam bulan paska penandatanganan FLEGT-VPA pada September 2013 hingga Maret 2014 naik sekitar 17,6 juta dolar AS atau 7,2 \% menjadi 260,3 juta dolar AS dibandingkan periode yang sama tahun sebelumnya sebesar 242,8 juta dolar AS. Serbuk gergajian kayu atau sering disebut tepung kayu didefinisikan sebagai selulosa kayu halus-tanah, sering disebut "serat kayu". Hal ini digunakan dalam pembuatan berbagai macam produk dari komposit decking eksterior untuk interior dinding ruangan yang memerlukan kedap suara. Akar wangi (Vetiveria Zizanioides) sebenarnya banyak dijumpai di berbagai daerah di Indonesia. Pasalnya, tanaman ini kerap dijumpai tumbuh secara liar atau setengah liar. Sayangnya banyak warga masyarakat yang mengabaikannya, padahal akar wangi bisa diolah menjadi aneka produk bernilai ekonomi cukup tinggi dan bukan hanya memiliki nilai ekonomi, tetapi juga mampu menghijaukan lahan kritis dan menekan potensi terjadinya longsor

\section{Bahan Komposit}

Bahan komposit pada umumnya terdiri dari dua unsur, yaitu serat (fiber) sebagai bahan pengisi dan bahan pengikat serat-serat tersebut yang disebut matrik. Pengunaan serat sendiri yang utama untuk menentukan karakteristik bahan komposit, seperti : kekakuan, kekuatan, daya sereap/redam terhadap suara serta sifat-sifat mekanik yang lainnya. Salah satu keuntungan material komposit adalah kemampuan material tersebut untuk diarahkan sehingga kekuatannya dapat diatur hanya pada arah tertentu yang kita kehendaki, hal ini dinamakan "tailoring properties" dan ini salah satu sifat istimewa komposit yaitu ringan, kuat, tidak terpengaruh korosi, dan mampu bersaing dengan logam, dengan tidak kehilangan karakteristiknya.

Komposit merupakan terobosan baru dalam ilmu bahan sebagai bahan konstruksi selain logam/metal. Seiring dengan perkembangannya ilmu komposit, komposit bermetrik polimer mengalami pertumbuhan yang sangat pesat dan ada kecenderungan dalam perkembangannya material komposit bergeser pada penggunaan kembali serat alam (back to nature) sebagai pengganti serat sintetik. Demikian juga komposit antara serat batang pisang dan serbuk gergajian kayu mempunyai kemampuan untuk bisa dijadikan bahan pembuatan produk meskipun kekuatannnya lebih rendah dari komposit antara serat sabut kelapa dan serbuk gergajian kayu, namun komposit ini kemampuan untuk daya redamnya lebih baik sehingga lebih cocok untuk interior ruangan yang memerlukan kedap suara. (Purwanto, dkk, 2014). Berdasarkan hasil penelitian yang sudah dilakukan maka dilakukan penelitian tentang pembuatan komposit dari bahan limbah yang serbuk gergajian kayu dan serat akar wangi untuk menghasilkan komposit yang mempunyai sifat redam suara untuk pembuatan bahan pembuat ruangan yang kedap suara. Dengan diperolehnya bahan komposit yang mempunyai sifat peredam suara/daya absorpsi suara yang seperti bahan lain misal kayu maka bahan komposit tersebut dapat dijadikan bahan dasar alternatif dalam pembuatan produk yang membutuhkan daya absorpsi misalnya dinding mobil, dinding ruangan maupun peralatan kotak speaker. 


\section{Metode Penelitian}

Dalam penelitian ini metode yang digunakan adalah eksperimen di Laboratorium, untuk uji akustik sesuai standart ASTM E-1050-98 dengan instrument uji B\&K 4206 Small Tube Set yang selanjutnya dilakukan pengamatan strukturnya secara mikro untuk mengetahui struktut seratnya. Material uji/spesimen dibuat berbentuk poros yang merupakan komposit antara serat alam akar wangi (SAW) dan serbuk gergajian kayu (SGK) dengan bahan pengikat lem kayu. Sampel benda uji dibuat dengan 5 perlakuan substitusi berat serat alam akar wangi dan serbuk gergajian kayu dengan perbadingan fraksi berat 1:5, 2:5, 3:5, 4:5, 5 5;5. Pencampuran dilakukan dengan mixer sampai campuran cukup homogen dengan waktu selama 5 menit.

\section{Pembahasan}

Komposit antara serat akar wangi (SAW) dan serbuk gergajian kayu (SGK) hasil penelitian yang kemudian dilakukan pengujian akustik hasilnya ditunjukkan pada Gambar 1. Untuk pengujian di dua daerah frekuensi suara yaitu frekuensi suara rendah $(<2500 \mathrm{~Hz}$ ) yaitu $1000 \mathrm{~Hz}$ dan daerah frekuensi suara tinggi (> $2500 \mathrm{~Hz})$ yaitu 5000 Hz. Pada gambar tersebut kode specimen, misalnya: SAW10,SGK50 berarti specimen dengan perbandingan antara serat akar wangi (SAW) dan serbuk gergajian kayu (SGK) 1:5 dan seterusnya. Dari gambar grafik terlihat bahwa nilai koefisien peredaman $(\alpha)$ untuk daerah frekuensi rendah $(1000 \mathrm{~Hz})$ sebesar 0,25 untuk komposisi perbandingann 2:5 (SAW20,SGK50), sedangkan pada daerah frekuensi tinggi $(5000 \mathrm{~Hz})$ nilai koefisien peredamam suara $(\alpha)$ terjadi pada komposisi perbandingan 1:5 (SAW10,SGK50) sebesar 0,40 .

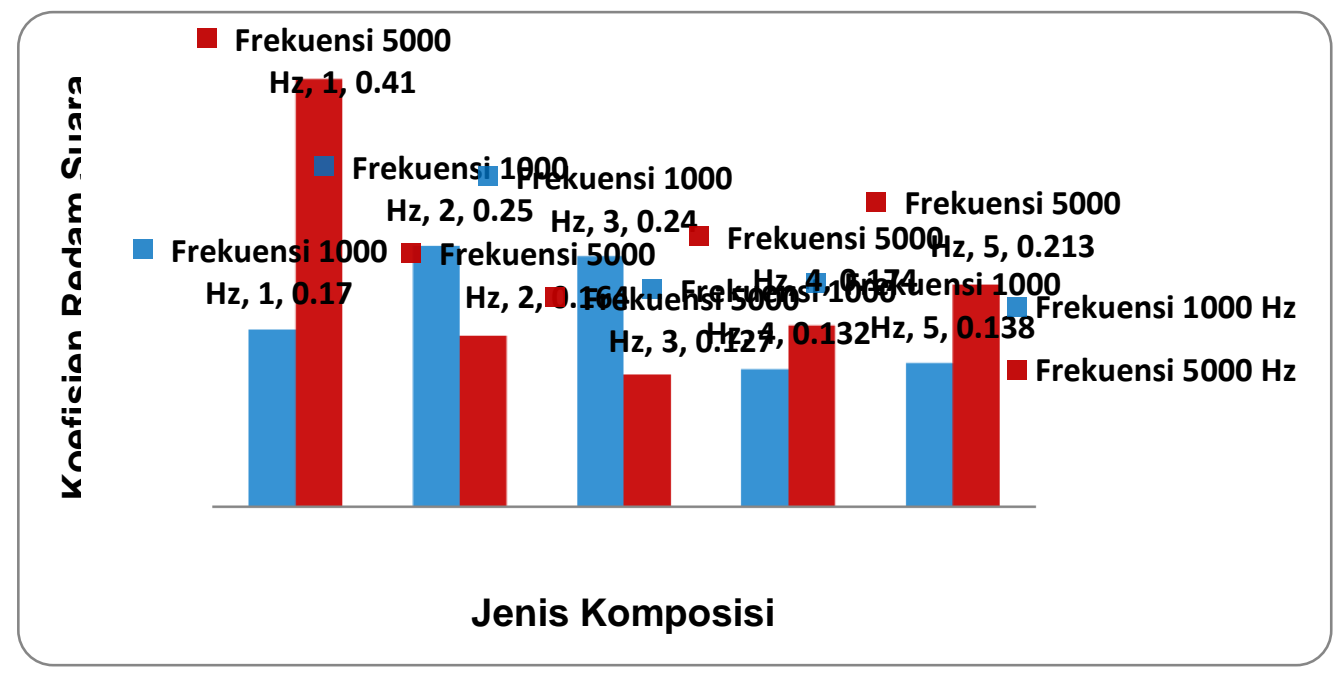

Gambar 1. Koefisien Peredaman Suara pada Frekuensi $1000 \mathrm{~Hz}$ dan $5000 \mathrm{~Hz}$

Selanjutnya komposit hasil penelitian ini bila dibandingkan dengan bahan lain pada frekuensi rendah $(1000 \mathrm{~Hz})$ nilai koefisien peredaman suaranya ditunjukkan pada Gambar 2. Dari grafik tersebut terlihat bahwa komposit angtara SAW dan SGK yang dihasilkan nilai koefisien peredamannya setara dengan bahan Gypsum dan lebih baik dari bahan Play wood (http://www.acoustic.ua/st/web_absorption_data_eng.pdf) maupun Styrofoam (Jurnal Fisika UNES, 2013). 


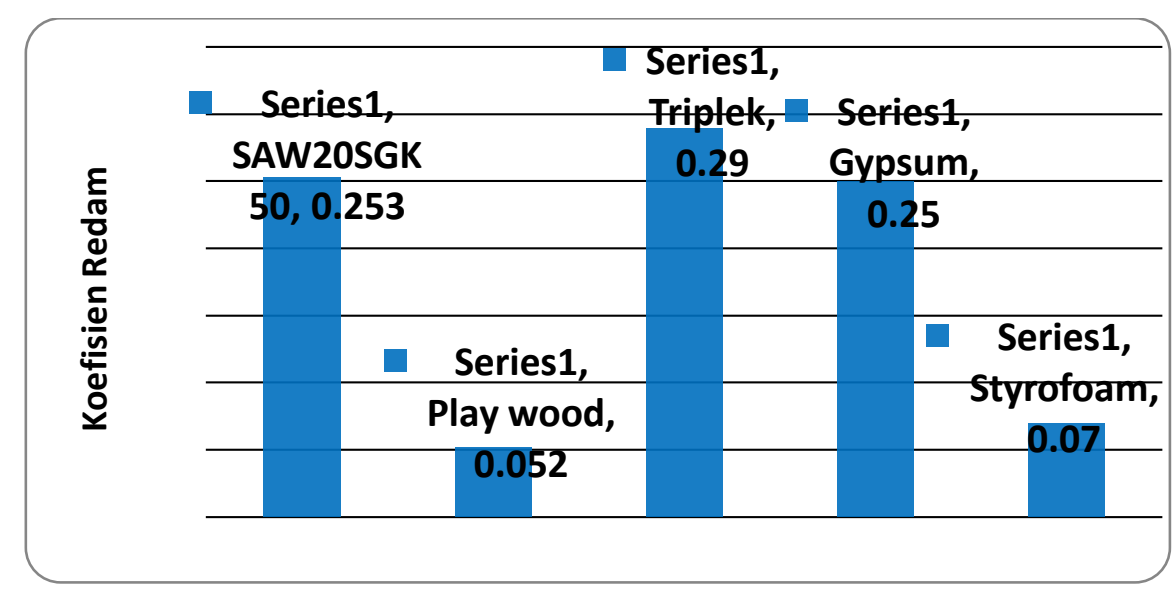

Jenis Material

Gambar 2. Perbandingan Koefisien Redam Suara pada Frekuensi 1000 Hz

Dalam uji struktur mikro komposit antara serat akar wangi (SAW) dan serbuk gergajian kayu (SGK) maka volume dari serat akar wangi sebagai penguat akan mempengaruhi kekuatan dari komposit tersebut. Berdasarkan hasil penelitian yang telah dilakukan bahwa komposit dengan komposisi perbandingan antara SAW dan SGK mulai 1:5 sampai dengan komposisi perbandingan 5:5 terjadi peningkatan secara linier dengan hasil kekuatan tarik mencapai 29,3 kg/mm² (Purwanto, 2016). Kekuatan tarik sebesar ini termasuk dalam golongan kayu kelas II, yang termasuk golongan kayu kelas ini adalah kayu bengkirai, cemara, cendana, gelam, kruing, mahoni dan meranti (PPKI, 1961). Berdasarkan hasil pengamatan struktur mikro seperti ditunjukkan pada Gambar 3, jumlah serat yang paling banyak yaitu pada komposisi 5:5.

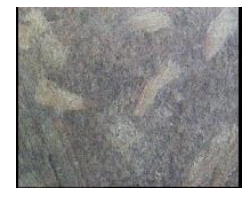

SAW10,SGK

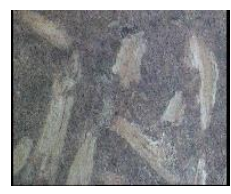

SAW20,SGK

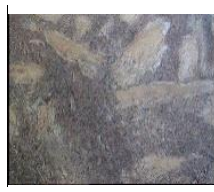

SAW30,SGK

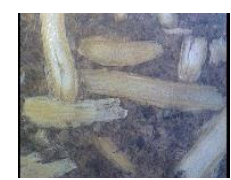

SAW10,SGK

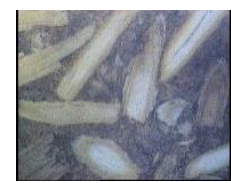

SAW10,SGK

Gambar 3. Struktur Mikro Komposit SAW dan SGK

\section{Kesimpulan}

Berdasarkan hasil penelitian yang telah dilakukan maka dapat disimpulkan sebagai berikut: (1) Komposit antara serat alam akar wangi dan serbuk gergajian kayu mempunyai kemampuan sebagai peredam suara $(\alpha=0,253)$ lebih baik bila dibandingkan dengan bahan play wood $(\alpha=0,053)$ dan styrofoam $(\alpha=0,07)$, namun setara dengan bahan gypsum $(\alpha=0,25)$. (2) Kemampuan redam terhadap suara yang paling baik terjadi 
pada perbandingan faraksi berat serat dan serbuk yaitu 1:5 untuk frekuensi tinggi (5000 $\mathrm{Hz})$, sedangkan pada frekuensi rendah $(1000 \mathrm{~Hz})$ terjadi pada perbandingan fraksi berat antara serat dan serbuk yaitu 2:5. (3) Komposit antara serat alam akar wangi dan serbuk gergajian kayu semakin banyak komposisi serat akar wanginya maka kekuatan tariknya semakin meningkat yang terjadi pada komposisi perbandingan 5:5.

\section{Daftar pustaka}

Debabrata Chowdhury (2010). Study on Mechanical Behaviour of Wood Dust Silled Polymer Composites, Thessis.

Emmy Dyah S, dkk (2012), Pengaruh Panjang Serat dan Fraksi Volume terhadap Kekuatan Impact dan Bending Material Komposit Polyester-fiberglass dan Polyester-Pandan -Wangi, Dinamika Teknik Mesin, No.2 Volume 1, Januari 2012

Fatkhurrohman M.A, et al., Tingkat Redam Bunyi Suatu Bahan, Jurnal Fisika Vol. 3 No. 2, Nopember 2013

Ismail, H, (2008), Komposit Polimer Diperkuat Pengisi dan Gentian Pendek Semula Jadi,

Penerbit Universiti Sains Malaysia, Pulau Penang.

Nasmi Herlina S, (2013), Karakteristik Kekuatan Bending Kayu Komposit Polyester diperkuat Serat Pandan Wangi dengan Filler Serbuk Gergajian Kayu, Jurnal Energi dan Manufaktur, Volume 6, No.2, Oktober 2013

Purwanto, (2016). Pembentukan komposit antara serat akar wangi dan limbah serbuk gergajian kayu sebagai bahan dasar alternative pembuatan sadel sepeda balap, Hasil Penelitian, LPPM UKDW Yogyakarta

Purwanto (2014), Pengaruh komposisi terhadap sifat fisis dan mekanis komposit antara limbah serbuk gergajian kayu dan serat alam batang pisang ", Hasil Penelitian, LPPM UKDW Yogyakarta

Peraturan Konstruksi Kayu Indonesia. PKKI, N.15. 1961. Departemen Pekerjaan

Umum dan Tenaga Listrik: Bandung (ID).

Shauw A.H dan Din R.H (2008), Gentian dan Komposit Lignoselulosik. Penerbit Universit Sains Malaysia, Pulau Pinang.

www.antaranews.com (2014), Eksport Kayu Indonesia ke Eropa Naik, (Selasa 6 Mei 2014)

http://www.acoustic.ua/st/web_absorption_data_eng.pdf 